\title{
Increased cell motility and invasion upon knockdown of lipolysis stimulated lipoprotein receptor (LSR) in SW780 bladder cancer cells
}

\author{
Malene Herbsleb ${ }^{1}$, Karin Birkenkamp-Demtroder ${ }^{1}$, Thomas Thykjaer ${ }^{1}$, \\ Carsten Wiuf ${ }^{2}$, Anne-Mette K Hein ${ }^{1}$, Torben F Ørntoft ${ }^{1}$ and Lars Dyrskjøt*1
}

Address: ${ }^{1}$ Molecular Diagnostic Laboratory, Department of Clinical Biochemistry, Aarhus University Hospital, Skejby, Brendstrupgaardsvej 100, DK-8200 Aarhus N, Denmark and 2BiRC - Bioinformatics Research Center, University of Aarhus, Hoegh-Guldbergs Gade 10, Building 1090, DK8000 Aarhus C, Denmark

Email: Malene Herbsleb - herbsleb@ki.au.dk; Karin Birkenkamp-Demtroder - kbdr@ki.au.dk; Thomas Thykjaer - thykjaer@ki.au.dk; Carsten Wiuf - wiuf@daimi.au.dk; Anne-Mette K Hein - anne.mette.hein@ki.au.dk; Torben F Ørntoft - orntoft@ki.au.dk;

Lars Dyrskjøt* - lars@ki.au.dk

* Corresponding author

Published: 22 July 2008

BMC Medical Genomics 2008, I:31 doi:10.1 |86/I755-8794-I-31

This article is available from: http://www.biomedcentral.com/1755-8794/I/3I

(c) 2008 Herbsleb et al; licensee BioMed Central Ltd.

This is an Open Access article distributed under the terms of the Creative Commons Attribution License (http://creativecommons.org/licenses/by/2.0), which permits unrestricted use, distribution, and reproduction in any medium, provided the original work is properly cited.
Received: 22 February 2008

Accepted: 22 July 2008

\begin{abstract}
Background: Mechanisms underlying the malignant development in bladder cancer are still not well understood. Lipolysis stimulated lipoprotein receptor (LSR) has previously been found to be upregulated by P53. Furthermore, we have previously found LSR to be differentially expressed in bladder cancer. Here we investigated the role of LSR in bladder cancer.

Methods: A time course siRNA knock down experiment was performed to investigate the functional role of LSR in SW780 bladder cancer cells. Since LSR was previously shown to be regulated by P53, siRNA against TP53 was included in the experimental setup. We used Affymetrix GeneChips for measuring gene expression changes and we used Ingenuity Pathway Analysis to investigate the relationship among differentially expressed genes upon siRNA knockdown.

Results: By Ingenuity Pathway analysis of the microarray data from the different timepoints we identified six gene networks containing genes mainly related to the functional categories "cancer", "cell death", and "cellular movement". We determined that genes annotated to the functional category "cellular movement" including "invasion" and "cell motility" were highly significantly overrepresented. A matrigel assay showed that $24 \mathrm{~h}$ after transfection the invasion capacity was significantly increased 3-fold $(p<0.02)$ in LSR-siRNA transfected cells, and 2.7-fold $(p<0.02)$ in TP53-siRNA transfected cells compared to controls. After $48 \mathrm{~h}$ the motility capacity was significantly increased 3.5-fold $(p<0.004)$ in LSR-siRNA transfected cells, and 4.7-fold $(p<0.002)$ in TP53-siRNA transfected cells compared to controls.
\end{abstract}

Conclusion: We conclude that LSR may impair bladder cancer cells from gaining invasive properties. 


\section{Background}

Completion of the human genome project $[1,2]$ together with development of microarray techniques have made it possible to investigate global changes in expression patterns that occur during bladder cancer development. Gene expression profiles associated with disease stage [3-7], disease progression $[4,7,8]$, recurrence pattern $[4]$, survival $[6,9]$, and treatment response [10] have been delineated by several groups. Other studies have focused on the impact of single genes on tumorigenesis like the oncogenes HRAS, FGFR3, ERBB2, CCND1, and MDM2, and the tumor suppressors CDKN2A, PTEN, TSC1, and DBC1 (recently reviewed in [11]). Thus, knowledge on molecular alterations of single parameters is available, but the complex network of molecular events leading to invasive bladder cancer still requires further attention.

In this study we have focused on the lipolysis stimulated lipoprotein receptor gene (LSR), which is differentially expressed in bladder cancer. LSR was identified in 1992 as a receptor distinct from the low density lipoprotein receptor $(L D L R)$ and low density lipoprotein-related protein 1 (LRP1) [12,13]. LSR binds ApoB and ApoE containing lipoproteins, especially chylomicrons and VLDL [12-15]. Unsaturated, long-chained ( $>12 \mathrm{C})$ free fatty acids like oleate activate the receptor by causing a conformational change that expose the binding site $[12-14,16]$. The apparent number of LSR binding sites expressed at the surface of hepatocytes correlates negatively with plasma triglyceride levels measures at the postprandial stage [14]. After binding to LSR, the ligands are internalised and proteolytic degraded in lysosomes $[12,13]$. LSR binding is inhibited by lactoferrin [12-14], receptor associated protein (RAP) [17], and apoC-III [18], which all are reported to have hyperlipidemic effects. Previously, in an effort to identify primary TP53 targets, LSR was found to be upregulated by TP53 [19]. In another study, LSR was downregulated more than 2 fold upon TGF- $\beta 1$ stimulation in wildtype cells with an active Smad4-TGF- $\beta$ signalling pathway [20].

Here we investigated the participation of LSR in SW780 bladder cancer cells motility and invasion. We used a siRNA knock down in vitro assay where LSR and TP53 were knocked down individually and in combination in SW780 bladder cancer cells. Time course microarray analyses were used to measure the global consequences of the knockdown. In silico prediction of LSR regulated motility and invasion was experimentally verified by a matrigel assay.

\section{Methods}

\section{Antibody synthesis}

Polyclonal rabbit anti-LSR antibodies were raised against the peptide
[C]VTSLHEDDWRSRPSR, aa 386-400, BC000015.2 6.6.2006) conjugated to the carrier protein KLH (Keyhole limpet hemocyanin) (Eurogentec, Belgium). CLUSTALW analysis matched the peptide sequence to all three isoforms I1 NP_057009.3 (630 aa), I2 NP_991403.1 (649 aa) and I3 NP_991404.1 (581 aa) as shown in Additional File 1.

\section{Cloning and overexpression}

cDNA was synthesized from total RNA from stage Ta tumors (non muscle invasive tumors) using SuperscriptTM cDNA synthesis kit (Invitrogen). cDNA was PCR amplified using primers sense 5'-ATGCAACAGGACGGACTTGG and antisense 3'-AGTCGGGAAAGTTTAGTCGTCTGA. The LSR PCR product was cloned into pcDNA 3.1 bidirectional (Invitrogen). Transient transfection with pcDNA 3.1_LSR isoform 1 and pcDNA 3.1_LSR isoform 3 of COS7 cells was achieved using FuGene (Roche) following the manufacturer's instructions yielding fragments with a 48 aa $\mathrm{N}$-terminal truncation.

\section{Cell extraction, SDS gels and Western blots}

COS7 cells transfected with pcDNA 3.1_LSR isoform 1 or isoform 3 were harvested by scraping and lysed in lysis buffer $(50 \mathrm{mM}$ Tris. HCl pH 8.0, $150 \mathrm{mM} \mathrm{NaCl}, 1 \mathrm{mM}$ DTT, $1 \%$ Triton X-100, protease inhibitor Roche complete, EDTA free). 10-20 $\mu \mathrm{g}$ total protein samples were run in 12\% SDS gels (Invitrogen) and transferred to PVDF membranes. Membranes were blocked with $3 \% \mathrm{w} / \mathrm{v}$ nonfat powder milk in PBS. The primary antibody was rabbit polyclonal anti-LSR (1:6000) and the secondary antibody goat anti-rabbit HRP conjugated (1:5000), DakoCytomation. The immunoreactive bands were visualised using ECL plus (Amersham biosciences) and an UVP ChemiDoc-It, Imaging system, UVP Inc.

\section{Immunohistochemistry}

Immunohistochemistry was performed using $4 \mu \mathrm{m}$ formalin fixed paraffin embedded (FFPE) sections of histological specimens as described previously [21]. We used a 1:3500 dilution of the rabbit polyclonal anti human LSRantibody. Staining was scored independently by two observers (L.D and M.H). Staining categories were defined as no, weak, moderate or strong staining. In case of disagreement, the samples were re-evaluated and a consensus scoring was achieved.

\section{Knock down assay}

SW780 cells (ATCC, CRL-2169) were grown in D-MEM medium (Invitrogen, cat. no. 31885-023) supplemented with 10\% FCS (Invitrogen, cat.no. 10270-106) and 1\% penicillin/streptomycin (Invitrogen, cat. no. 15140-122) at $37^{\circ} \mathrm{C}$ in a humidified environment with $5 \% \mathrm{CO}_{2}$ atmosphere. The SW780 cells were selected for this study because they originate from a grade 1 tumor and hence 
resemble early steps in carcinogenesis before the cells become invasive. Cells were tested negative for Mycoplasma infection by MycoSensor PCR Assay set (Stratagene, cat. no. 302108, La Jolla, CA.).

Cells were harvested with Trypsin (cat.no. 25300-062). A nucleofector (Amaxa, Cologne, Germany) was used for cell transfections using Amaxa's standard program A23 [22]. For each siRNA construct $0.8 \times 10^{6}$ cells resuspended in $100 \mu \mathrm{l}$ solution $\mathrm{R}$ (standard solution) were transiently transfected with a total of $1.2 \mu \mathrm{g}$ siRNA using either mock siRNA (Non-targeting siRNA, Dharmacon, cat. no. D001210-01), TP53 siRNA (Dharmacon, cat. no. M003329-00), first LSR siRNA (LSR1, UCA AAG GUC AGG UCA GCA UTT, DNA Technology), second LSR siRNA (LSR2, siRNA ID 116788, Ambion), or $0.6 \mu \mathrm{g}$ TP53 siRNA plus $0.6 \mu \mathrm{g}$ LSR1. Transfected cells were grown for $18 \mathrm{~h}$ (one sample per siRNA construct), $48 \mathrm{~h}$ (4 samples per construct) or $72 \mathrm{~h}$ (one sample split in two technical replicates for further analysis).

Cells were harvested by scraping the flasks with $1 \mathrm{ml}$ lysis buffer and total RNA was extracted from the cells using GenElute Mammalian Total RNA Miniprep Kit (SigmaAldrich, St. Louis, MO, cat.no. RTN350) according to the manufacturer's instructions.

\section{Microarray analysis of cell lines}

Double stranded cDNA synthesis, in vitro transcription and labelling of cRNA, hybridisation and scanning was performed using standard procedures, see reference [5]. A total of thirty-five HG-U133 Plus 2 GeneChips (Affymetrix) were used.

\section{Data analysis of cell line microarray data}

The arrays were normalised and expression measures generated using the GCRMA method [23] implemented in the ArrayAssist software (Stratagene). GCRMA stands for GeneChip robust multi-array analysis - see reference $[22,24]$. The mean expression of TP53 and LSR was calculated for each transfection and time point using the probes for LSR (208190_s_at) and TP53 (201746_at). There are two probesets for TP53 on the HG-U133 Plus 2 GeneChip, however, the other probeset (211300_s_at) is not specific for TP53. Then, for each time point three filters were applied to identify differentially expressed genes. The first filter removed non-expressed transcripts, in the way that transcripts were kept if all replicate samples from at least one siRNA construct were at least $6(\log 2$ scale number). The second filter was applied for each knockdown experiment (TP53, LSR1, LSR2, LSR1+TP53). It included transcripts, where the mean expression of mock transfected cells or the mean expression of knock down transfected cells was at least 6 . An expression above 6 was defined as being above the noise threshold. Using these filters for the three time points gave twelve different subsets of probes with approximately 16,000 transcripts. A third filter was applied in Ingenuity, where a cut-off was applied to define "Focus Genes" as genes with a mean log ratio (compared to mock) of $\geq|1|$. We used Excel (Microsoft) for filtering the data.

\section{Bioinformatics using Ingenuity Pathway Analysis}

Each probe was mapped to its corresponding gene object in the Ingenuity Pathways Knowledge Base (IPKB). "Focus Genes" were superimposed the global molecular network developed from information contained in the IPKB. "Local networks" preferentially enriched of these Focus Genes were then generated based on their connectivity.

The "Functional Analysis of a network" identified the biological functions and/or diseases that were most significant to the genes in the network. The network genes associated with biological functions and/or diseases in the IPKB were considered for the analysis. Fischer's exact test was used to calculate a p-value determining the probability that each biological function and/or disease assigned to that network is due to chance alone.

The "Global Functional Analysis" identified the biological functions and/or diseases that were most significant to the entire data set. Genes from the dataset that met the log ratio cutoff of $\geq|1|$ and were associated with biological functions and/or diseases in the IPKB were considered for the analysis.

\section{Microarray data from human tissue samples}

We used an independent dataset previously generated using HG-U133A Affymetrix GeneChips [5] on 87 bladder carcinomas ( 55 Ta tumors, 3 T1 tumors, and 29 T2-4 tumors) and 9 samples of normal urothelium. Gene expression measures were generated and data normalized using the GCRMA method [23] implemented in the ArrayAssist software (Stratagene). Mean expressions and log ratios were calculated for tumor and normal samples. A cut-off of $\log$ ratio $\geq|1|$ and $p$-value $\leq 0.05$ was used to define "focus genes" in the network analysis.

\section{Realtime PCR}

We measured expression of LSR (Assay ID Hs00210880_m1), EMP3 (assay ID Hs00171319_m1), AGR2 (assay ID Hs00180702_m1), CTGF (assay ID Hs00170014_m1) and GAPDH (Assay ID Hs99999905_m1) using standard procedures (Applied Biosystems). All samples were amplified in triplicate in an ABI Prism 7000 Thermal Cycler according to instructions of the manufacturer. TP53 expression was measured using a standard SYBR Green assay. 


\section{Cell invasion assay}

BD BioCoat Matrigel Invasion Chambers (BD Biosciences, cat. no. 354480) were used. To measure motility and invasion an equal number of control inserts (motility) and matrigel inserts (invasion) were used. $0.8 \times 10^{6}$ cells were transfected with AMAXA program A23 with $1.2 \mu \mathrm{g}$ siRNA in $100 \mu \mathrm{l}$ AMAXA solution $\mathrm{R}$ (standard solution in the Amaxa system) according to the instructions of the manufacturer. 25,000 transfected cells in a total volume of 0.5 $\mathrm{ml}$ were seeded into the top well of the inserts in serum free medium. The lower well was filled with $750 \mu \mathrm{l}$ medium with serum. The transfected cells were allowed to grow and invade for $24 \mathrm{~h}$ and $48 \mathrm{~h}$. We chose the $24 \mathrm{~h}$ timepoint instead of the $18 \mathrm{~h}$ timepoint that was used for the microarray analysis in order allow an effect of siRNA knockdown on the protein level. Then the non-invading cells were scraped from the upper surface of the membrane and the cells on the lower side were stained with Hemacolor staining set (Merck, cat. no. 1.11674) and four images covering the membrane were immediately taken under microscope. Each siRNA construct was tested in triplicate in both control inserts and matrigel inserts and the mean number of invading cells was calculated.

\section{Cell viability assay}

A MTT (3-(4,5-Dimethylthiazol-2-yl)-2,5-diphenyltetrazolium bromide) ELISA assay (Roche, cat. no. 1-465-007) was used to test the impact of LSR and TP53 knockdown on cell viability. $0.8 \times 10^{6}$ SW780 cells were transfected with AMAXA program A23 with $1.2 \mu \mathrm{g}$ siRNA in $100 \mu \mathrm{l}$ AMAXA solution $\mathrm{R}$ for each siRNA construct. Cells were grown in quadruplicate in 96-wells microtiter plates with 12.000 cells per well in a total volume of $100 \mu \mathrm{l}$ medium. After $24 \mathrm{~h}, 48 \mathrm{~h}$ or $72 \mathrm{~h} 10 \mu \mathrm{l}$ MTT was added to a final conc. $0.5 \mathrm{mg} / \mathrm{ml}$ and cells were allowed to incubate for four hours. $100 \mu \mathrm{l}$ solubilization solution was added to each well and the cells were lysed during incubation overnight. The absorbance was measured at $540 \mathrm{~nm}$ and 690 nm on a ELISA reader.

\section{Results}

\section{Cloning and overexpression of LSR}

From the data generated in a previous microarray screening of bladder tumors [5] we identified LSR as an interesting candidate gene for further analysis. Therefore, polyclonal rabbit anti-LSR antibodies were raised to characterise LSR protein expression. PCR amplification identified two transcript isoforms present in human bladder cancer, variants 1 and 3, while variant 2 was not amplified. Incubation of COS7 extracts overexpressing N-terminal truncated proteins of variant 1 or variant 3 showed that the antibody identified two LSR protein variants of about $65 \mathrm{kDa}$ and $59 \mathrm{kDa}$ (Figure 1) with a high specificity.

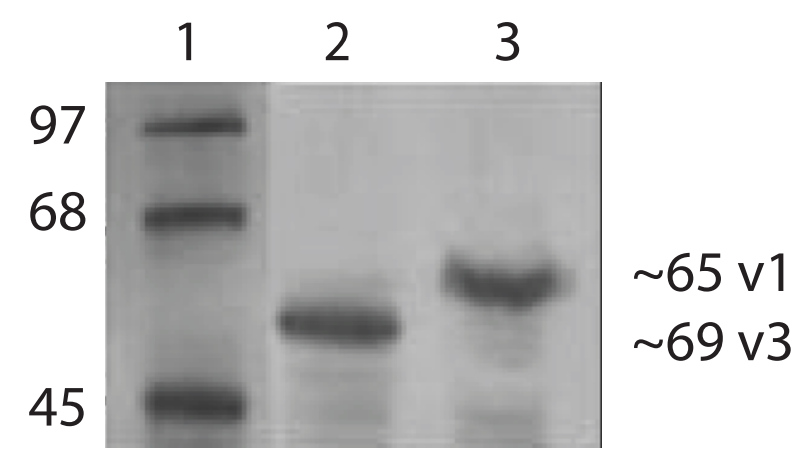

Figure I

Transient overexpression of truncated LSR isoforms $I(v I)$ and 3 (v3) in COS7 cells. Cell extracts were western blotted and identified by staining with polyclonal rabbit antibody. Lane I; Mol. weight markers,; lane 2, LSR isoform I; lane 3, LSR isoform 3.

\section{Expression of LSR protein in bladder tumors}

Immunohistochemical analysis of FFPE tissue sections from normal urothelium and bladder tumors showed a moderate to strong cytoplasmic expression of LSR in $100 \%$ of normal samples and $70 \%$ of Ta tumors (Figure 2 ). The expression was observed in nearly all urothelial cells. The overall number of cells staining positive for LSR was significantly decreasing in T1 and T2-4 tumors (Kendall's tau b, one-sided p-value $=0.0188$ ), and only $38 \%$ of the muscle invasive samples showed moderate to strong cytoplasmic staining for LSR in the majority of cancer cells (Additional File 2). No staining was detected in connective tissue or lymphocytes.

\section{Microarray screening for LSR target genes}

To investigate the function of LSR we used siRNA knockdown in the bladder cancer cell line SW780, which showed a high endogenous level of LSR expression. SW780 was transiently transfected with siRNA and two siRNAs against LSR were used (LSR1, LSR2) to evaluate eventual off-target effects [25]. A possible relationship between LSR and TP53 has been shown previously [19] and therefore siRNA against TP53 was also included. LSR was knocked down alone or in combination with TP53 (LSR1+TP53). All knock down experiments were compared to cells transfected with a non-targeting siRNA (mock).

Cells were harvested after $18 \mathrm{~h}, 48 \mathrm{~h}$ and $72 \mathrm{~h}$ and microarray data documented that mean LSR expression was reduced significantly (Figure 3). Knockdown of TP53 transcripts had no impact on LSR expression at any time points. Measurements of TP53 expression showed that the siRNA against TP53 reduced the TP53 transcript level to $10 \%(18 \mathrm{~h}), 16 \%(48 \mathrm{~h})$, and $40 \%$ (72 h) compared to 

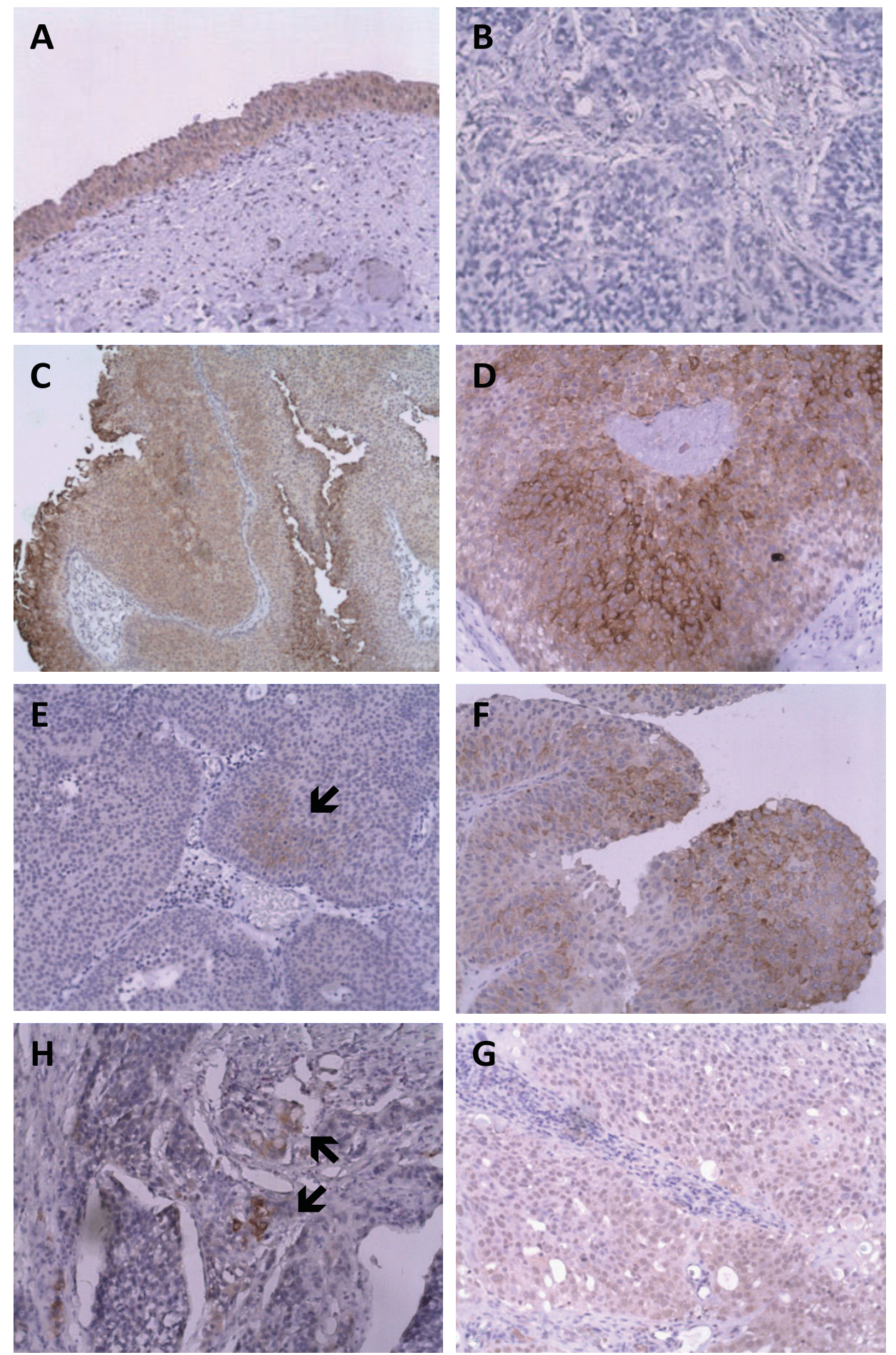

Figure 2

Immunohistochemical analysis of LSR expression in normal urothelium and bladder cancer samples. The protein was located in the cytoplasm in $>50 \%$ of the cancer cells. Original magnification, $\times 20$ (all except C), $\times 10$ (C). A: Normal bladder urothelium (21859-99); medium LSR expression. B: Negative control stain without primary antibody of T3 grade 3 tumor (6268-96). C-D: Ta grade 2 bladder tumor (4232-97); median LSR expression. E: TI grade 2 bladder tumor (60।8-98); weak LSR expression. F: TI grade 3 bladder tumor (5248-02); medium LSR expression. G: T3 grade 3 bladder tumor (626896); weak LSR expression. H: T2 grade 3 bladder tumor (17/9-00); weak, overall LSR expression in cytoplasm and nucleus. 
LSR expression
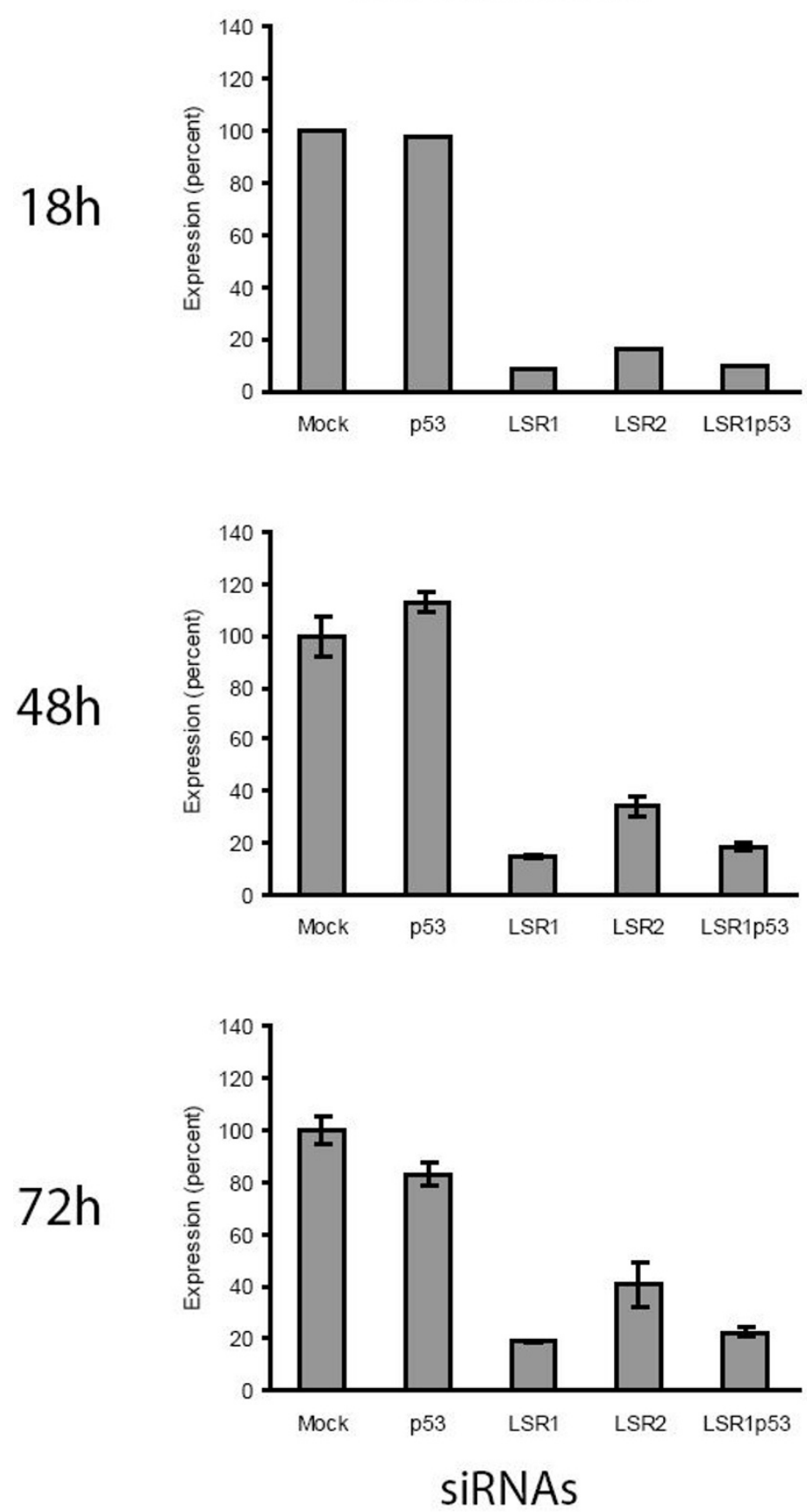

TP53 expression
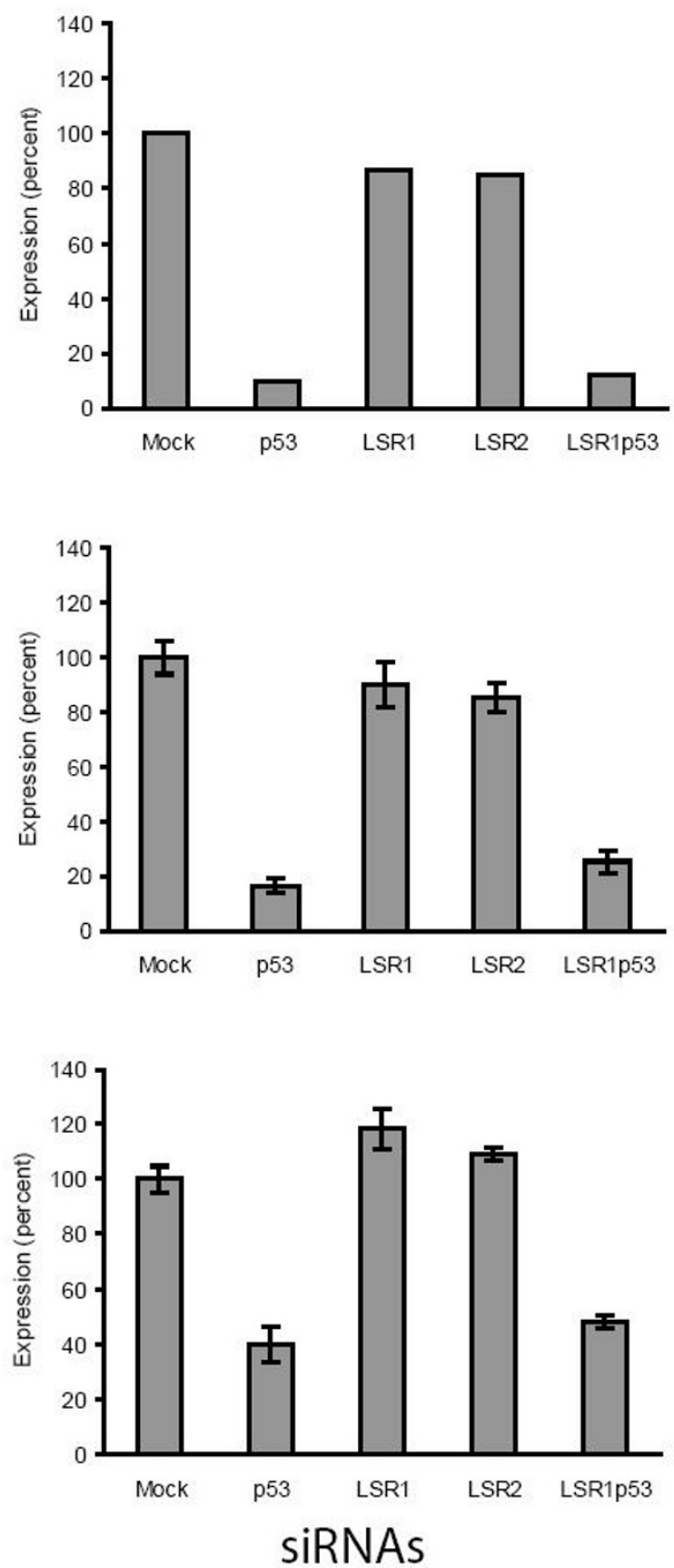

Figure 3

Transient transfection of SW780 bladder cancer cells with a non-targeting siRNA (Mock), two different siRNAs against LSR (LSRI, LSR2), one siRNA against TP53 (TP53) and siRNA against LSR and TP53 in combination (LSRI+TP53). Transfected cells were harvested $18 \mathrm{~h}$ (one sample per siRNA constructs), $48 \mathrm{~h}$ (4 samples per construct) or $72 \mathrm{~h}$ (one sample split in two technical replicates for further analysis) after transfection and gene expression was measured using microarray analysis (HG-UI33 Plus 2 arrays, GeneChip, Affymetrix). The figure shows normalized mean expression of LSR (first graph column) and TP53 (second graph column). Error bars indicate +/- one standard deviation. 
mock transfected cells, while knockdown of LSR had no effect on TP53 expression.

\section{Overlapping effects of two LSR siRNAs}

We found a large overlap in transcripts affected by LSR1 and LSR2, confirming that overall, the two LSR siRNAs had similar effect (Additional File 3). Furthermore, transcripts consistently affected over the three time points by each of the two siRNAs showed considerable overlap (Additional File 3); the sixteen common genes are shown in Table 1 . The majority (44\%) of these genes encoded proteins annotated to be located in the extracellular space like CYR61.

\section{Knockdown effects and QPCR verification}

A large number of genes were found to be differentially expressed upon knockdown (Additional File 4). $48 \mathrm{~h}$ after transfection, the microarray analysis showed a significant upregulation (1.6-fold, $\log 2$ scale) of the EMP3 expression (t-test, one-sided $\mathrm{P}=9.9 \times 10^{-6}$ ) and CTGF expression (2.6 fold)( $\mathrm{t}$-test, one-sided $\left.\mathrm{P}=5.6 \times 10^{-5}\right)$, while AGR2 expression was significantly downregulated $(-1.5$ fold) (ttest, one-sided P $\left.=1.3 \times 10^{-5}\right)$. QPCR analysis likewise showed a significant differential regulation of the expression of EMP3 (t-test, $\mathrm{P}=7.0 \times 10^{-12}$ ), CTGF (t-test, $\mathrm{P}<1.0$ $\times 10^{-12}$ ), and AGR2 (t-test, one-sided P $=8.4 \times 10^{-10}$ ). This consistency was also found for the measurements $72 \mathrm{~h}$ after transfection.

\section{Bioinformatics analysis of the knockdown effects: Local network analysis}

Using Ingenuity Pathway Analysis (IPA) we analysed the relationship between genes with a changed expression after knockdown of LSR, TP53 or both. "Local networks" preferentially enriched for "focus genes" were generated and ranked based on their connectivity (see Additional File 5).

Down-regulation of TP53: We found that the highest ranked local network upon downregulation of TP53 contained 35 focus genes (Figure $4 \mathrm{~A}$ ), which were annotated to the functional categories "cancer", "cellular growth and proliferation", and "cell death" ( $\mathrm{p}$-values between 6.6E-13 $-4.1 \mathrm{E}-12)$.

Down-regulation of LSR: The highest ranked local network was annotated to functional categories like "cell growth and proliferation", "cell death", "cancer", and "cellular movement" dominated ( $\mathrm{p}$-values between $2.72 \mathrm{E}-14-1.8 \mathrm{E}-8)$. The majority of the genes in these networks were up-regulated (Figure 5, 6). CYR61, EGR1, and $A K A P 12$, three of the genes constitutively regulated by both LSR siRNAs, were included in these networks (CYR61, Figure 5A and Figure 6A; EGR1, Figure 5B and Figure 6B; AKAP12, Figure 6B).

Table I: Consistently differentially expressed genes at all measurements after LSR knock down by both LSR siRNAs (log2 scale).

\begin{tabular}{|c|c|c|c|c|c|c|c|c|}
\hline \multirow[t]{2}{*}{ Location } & & \multirow[t]{2}{*}{ Gene } & \multicolumn{3}{|c|}{ LSRI } & \multicolumn{3}{|c|}{ LSR2 } \\
\hline & & & $18 \mathrm{~h}$ & $48 \mathrm{~h}$ & $72 \mathrm{~h}$ & $18 \mathrm{~h}$ & $48 \mathrm{~h}$ & $72 \mathrm{~h}$ \\
\hline Cytoplasm & AKAPI 2 & A kinase (PRKA) anchor protein (gravin) 12 & 1.2 & 1.8 & 1.9 & 1.1 & 2.1 & 2.1 \\
\hline \multirow[t]{7}{*}{ Extracell. Space } & FST & follistatin & 1.8 & 3.2 & 2.8 & 1.9 & 3.9 & 3.6 \\
\hline & APLP2 & amyloid beta (A4) precursor-like protein 2 & 1.3 & 1.6 & 1.1 & 1.3 & 1.6 & 1.2 \\
\hline & ILIA & interleukin I, alpha & 1.3 & 2.0 & 1.7 & 1.4 & 2.1 & 2.2 \\
\hline & CYR6I & cysteine-rich, angiogenic inducer, $6 \mathrm{I}$ & I.I & 2.6 & 2.2 & 1.0 & 2.3 & 2.6 \\
\hline & EDNI & endothelin I & 1.2 & 3.1 & 1.8 & 1.2 & 2.7 & 2.6 \\
\hline & GLIPR I & GLI pathogenesis-related I (glioma) & 1.4 & 2.2 & 2.6 & 1.7 & 2.8 & 2.8 \\
\hline & PTHLH & parathyroid hormone-like hormone & 1.5 & 3.3 & 3.8 & 1.0 & 3.0 & 3.2 \\
\hline \multirow[t]{2}{*}{ Nucleus } & EGR I & early growth response I & 2.0 & 3.7 & 2.5 & 2.9 & 1.6 & 3.5 \\
\hline & MYOCD & myocardin & 1.1 & 1.9 & 2.1 & 1.1 & 1.5 & 1.8 \\
\hline \multirow[t]{4}{*}{ Plasma Membrane } & TSPAN8 & tetraspanin 8 & -1.1 & -1.9 & -2.5 & -1.9 & -3.1 & -3.0 \\
\hline & MALL & mal, T-cell differentiation protein-like & 1.7 & 1.3 & 1.1 & 1.4 & 1.5 & 1.3 \\
\hline & NEXN & nexilin ( $F$ actin binding protein) & 1.4 & 1.5 & 1.3 & 1.4 & 1.7 & 1.4 \\
\hline & LSR & lipolysis stimulated lipoprotein receptor & -3.6 & -2.8 & -2.4 & -2.6 & -1.6 & -1.3 \\
\hline \multirow[t]{2}{*}{ Unknown } & TMCOI & transmembrane and coiled-coil domains I & 2.0 & 1.8 & 1.4 & 1.9 & 1.7 & 1.3 \\
\hline & TRIM3I & tripartite motif-containing 31 & -1.3 & -2.0 & -1.5 & -1.2 & -1.9 & -1.7 \\
\hline
\end{tabular}

Genes in bold are known by the Ingenuity Pathway Knowledge Base. Figures indicate log2 fold change at various time points. 

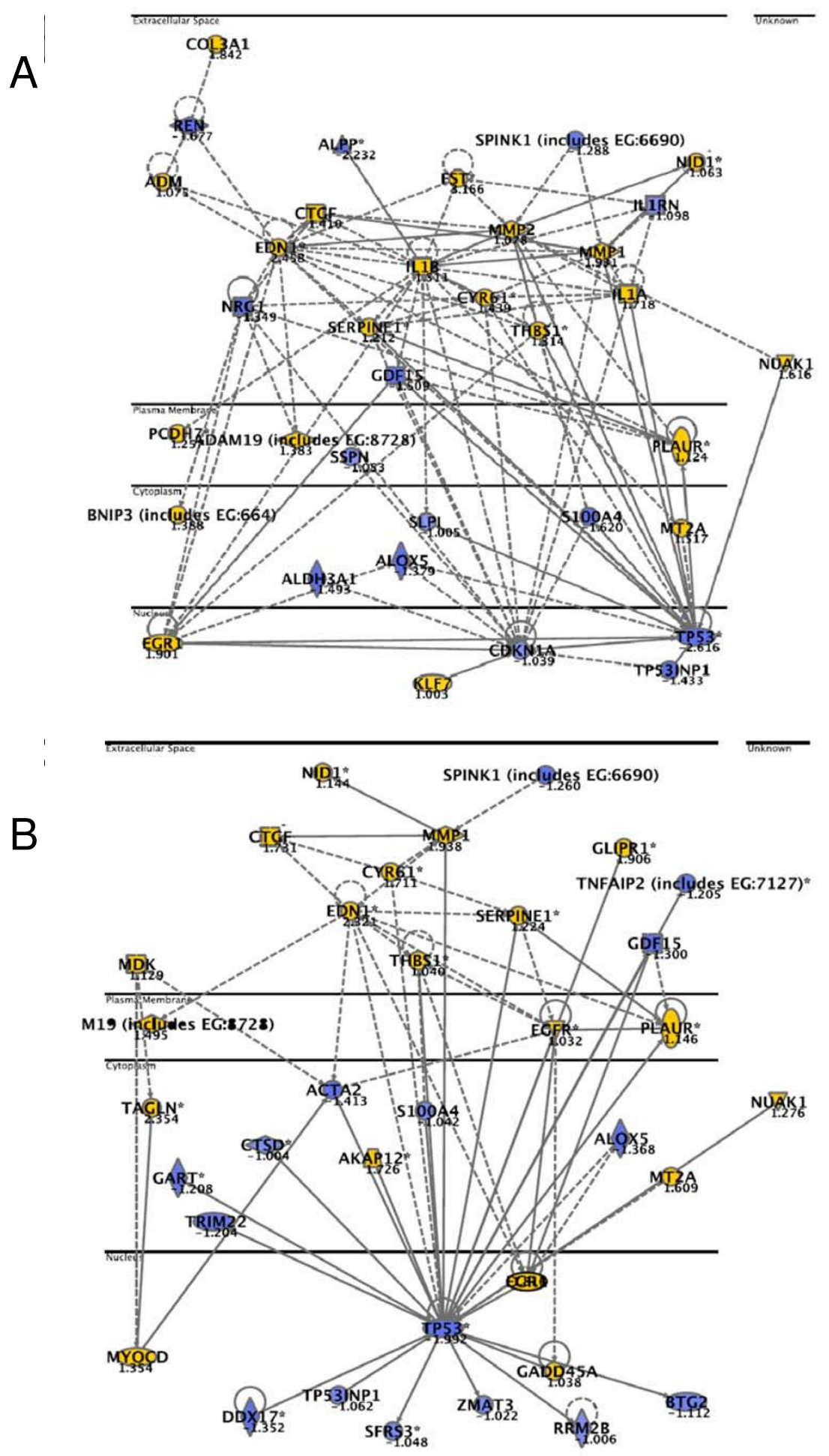

\section{Figure 4}

Networks top-ranked by Ingenuity Pathway analysis after knockdown of TP53 (A) and LSRI+TP53 (B). Coloured genes are upregulated (yellow) or downregulated (blue) more than 2-fold. "Focus genes" (bold) were defined as genes with a mean log ratio of $\geq|\mathrm{I}|$ compared to mock transfected cells. The horizontal lines separate different cellular compartments. 

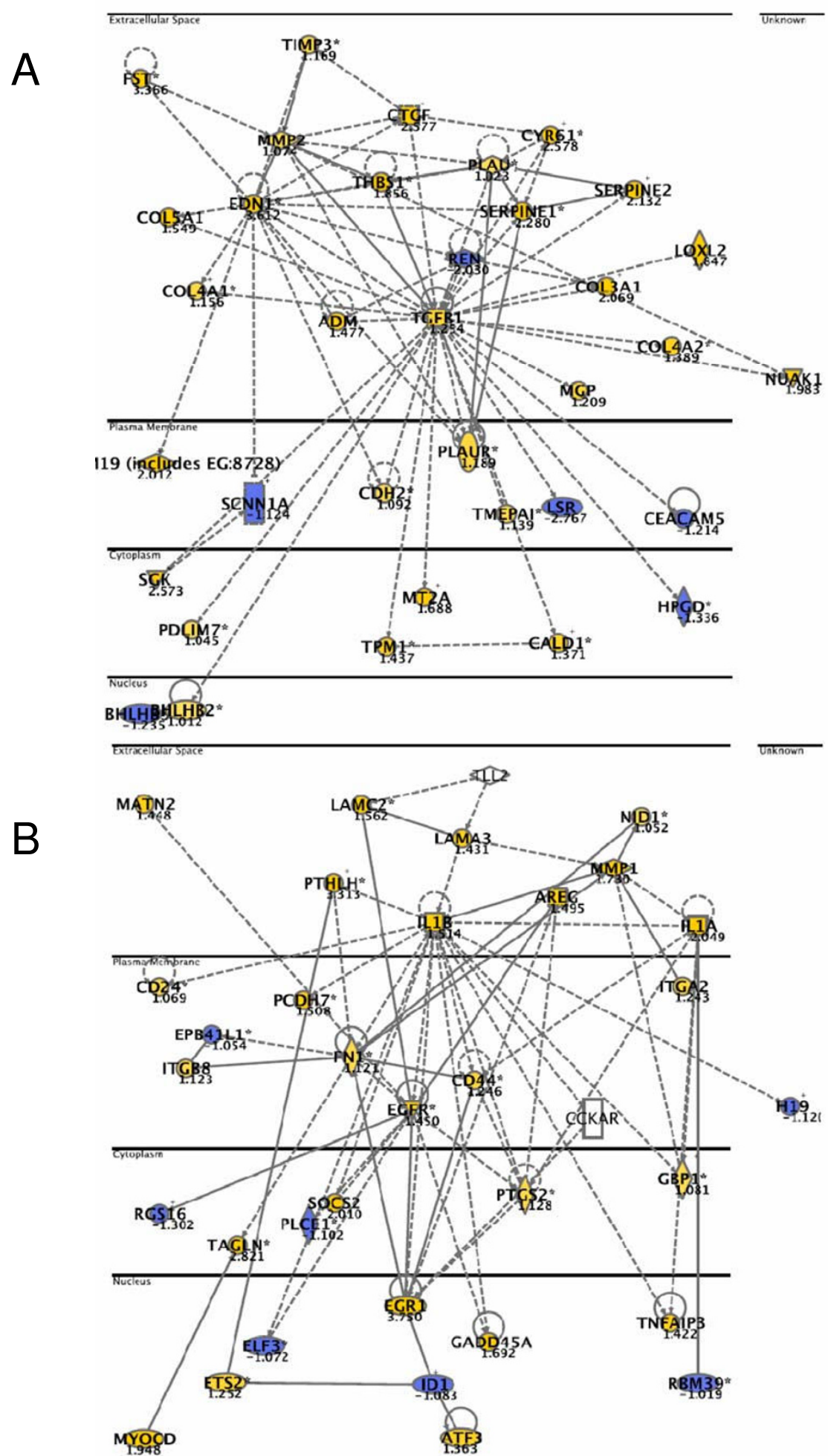

\section{Figure 5}

Networks top-ranked by Ingenuity Pathway analysis after knockdown of LSRI (A-B). Coloured genes are upregulated (yellow) or downregulated (blue) more than 2-fold. "Focus genes" (bold) were defined as genes with a mean log ratio of $\geq$ III compared to mock transfected cells. The horizontal lines separate different cellular compartments. 

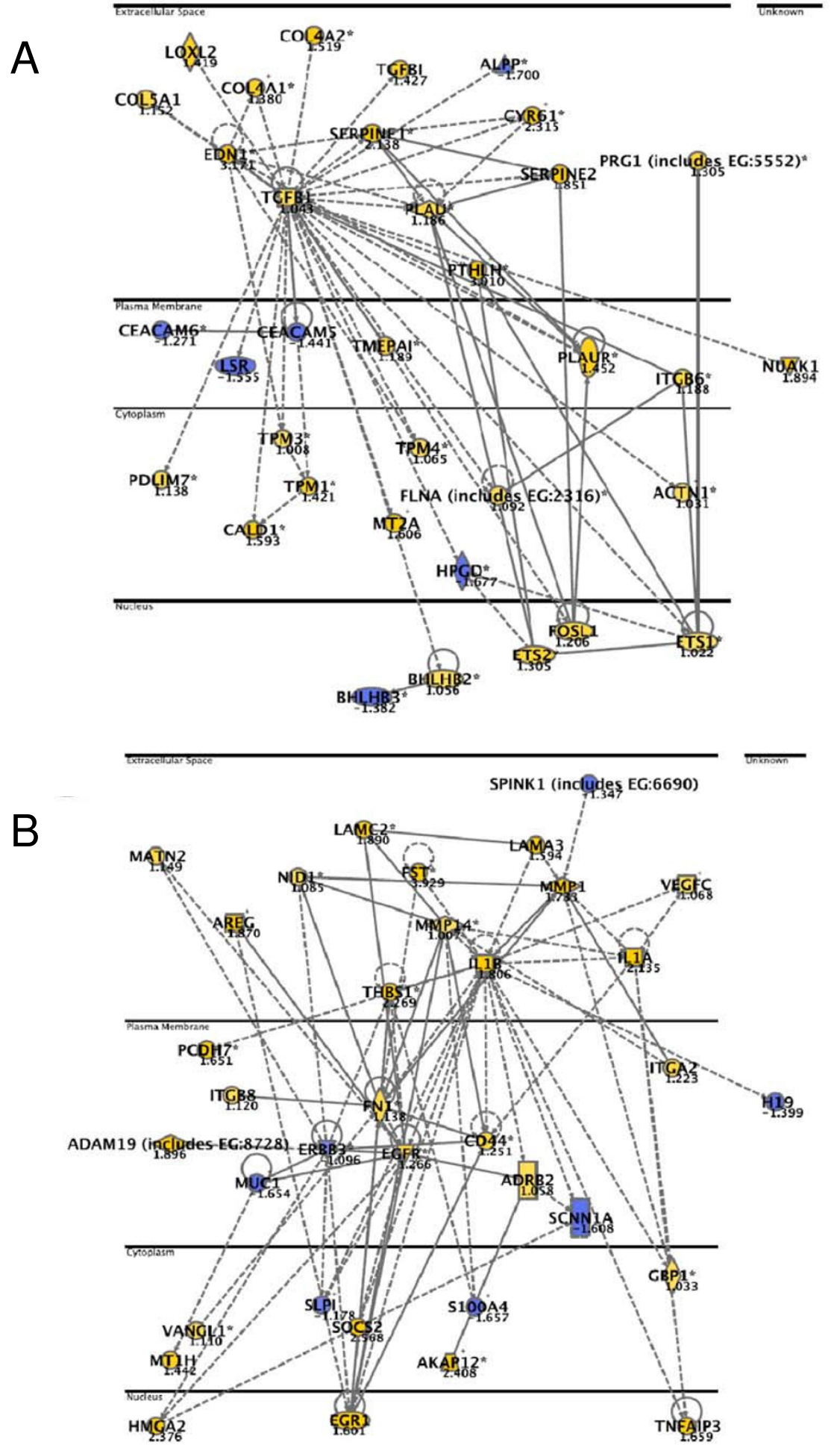

\section{Figure 6}

Networks top-ranked by Ingenuity Pathway analysis after knockdown of LSR2 (A-B). Coloured genes are upregulated (yellow) or downregulated (blue) more than 2-fold. "Focus genes" (bold) were defined as genes with a mean log ratio of $\geq$ III compared to mock transfected cells. The horizontal lines separate different cellular compartments. 
Down-regulation of TP53 and LSR in combination, $48 \mathrm{~h}$ : The highest ranked local network upon downregulation of TP53 and LSR contained 35 focus genes (Figure 4B). These genes were annotated to the functional categories "cancer", "cell death", and "cellular growth and proliferation" (p-values between 5.1E-11 - 6.0E-11).

\section{Bioinformatics analysis of the knockdown effects: Global functional analysis}

Using IPA a "global functional analysis" identified the biological functions, processes or diseases that were most relevant for the entire dataset.

Knockdown of TP53: We investigated the global functional consequences of TP53 knockdown (Table 2). We found, that $48 \mathrm{~h}$ after transfection the functions affected were related to "cell-to-cell signalling" $\left(\mathrm{P}=1.17 \times 10^{-10}\right)$, "organism survival" $\left(\mathrm{P}=1.74 \times 10^{-9}\right)$, and "cellular growth and proliferation" $\left(\mathrm{P}=1.29 \times 10^{-8}\right)$. The cell death/survival effect was even more prominent $18 \mathrm{~h}$ after transfection where all the three top-ranked functions were related to "cell death and survival" $\left(\mathrm{P}=5.96 \times 10^{-9}-3.72\right.$ $\left.\times 10^{-8}\right)$. This is consistent with the fact that TP53 expression was most prominent $18 \mathrm{~h}$ after transfection, where the highest knockdown effect was observed.

Knockdown of LSR: We found that the three most significant functions or processes after knockdown with LSR1 were all related to "cellular movements" (cell movement, invasion of eukaryotic cells, and invasion of cell lines). This was highly significant with P-values between $3.26 \times$ $10^{-12}$ and $1.61 \times 10^{-9}$. For knock down of LSR with LSR2 the three top ranked functions were related to "cell movement" $\left(\mathrm{P}=2.72 \times 10^{-15}\right)$, "growth of tumor cell lines" $(\mathrm{P}$ $\left.=4.45 \times 10^{-12}\right)$, and "cell movement of eukaryotic cells" (P $\left.=4.54 \times 10^{-12}\right)$. The same tendency was found at $72 \mathrm{~h}$ where all top-three ranked functions affected by knockdown of LSR by either LSR siRNA were related to "cellular movement" $\left(\mathrm{P}=5.60 \times 10^{-15}-2.46 \times 10^{-9}\right)$. See Table 2 .

Knockdown of LSR and TP53: For knock down of LSR and TP53 expression in combination the most significant function affected was related to "renal and urological disorder" $\left(\mathrm{P}=3.87 \times 10^{-8}\right)$. This was even more significant 72 $\mathrm{h}$ after transfection $\left(\mathrm{P}=8.15 \times 10^{-9}\right)$. Genes involved in that process were EDN1, GADD45A, IL1A, MT2A, PTHLH, REN, RRM2B, SERPINE1, THBS1, TGFB1, UPK2, and $V E G F$. Other highly significant functions were "cancer growth of tumor cell lines" $\left(\mathrm{P}=1.99 \times 10^{-7}\right)$, and "cellular growth" and "proliferation" (colony formation of eukaryotic cells $)\left(P=5.94 \times 10^{-7}\right)$. See Table 2 .

In conclusion, our in vitro experiment indicated that knock down of LSR affected genes known to be involved in cancer and especially cellular movements like invasion, migration and motility.

\section{Verification of the invasive potential of LSR knockdown}

Using a matrigel assay we measured the motility and invasion capacity after knockdown of LSR or TP53 to investigate the in silico predicted functional role of LSR. The SW780 bladder cancer cell line was transfected with siRNAs against LSR (LSR1), TP53 and LSR1+TP53. A mock siRNA was used as control. The experiment showed that $24 \mathrm{~h}$ after transfection, the invasion capacity was significantly elevated 3-fold in LSR1 knock-down cells ( $\mathrm{P}=$ 0.0194 ) and 2.7-fold in TP53 knock-down cells ( $\mathrm{P}=$ 0.0203 ) compared to mock transfected cells (Figure 7). After $48 \mathrm{~h}$ cell motility was elevated 3.5-fold in LSR1 knock down cells $(\mathrm{P}=0.0044)$ and 4.7 -fold in TP53 knock-down cells $(\mathrm{P}=0.0020)$ compared to mock transfected cells (Figure 7 ). There was no significant effect on motility $24 \mathrm{~h}$ after transfection, and no effect on invasion $48 \mathrm{~h}$ after transfection. There was no significant effect of knockdown with siRNAs against LSR and TP53 in combination.

\section{Measurement of cell viability after knockdown of LSR and TP53}

Since our "global functional analysis" showed that knockdown of TP53 transcripts influenced genes involved in cell death and cell survival we conducted a viability assay to measure if there were any difference in number of viable cells. Further, we wanted to see, if the invasion capacity of LSR knock down cells was due to difference in viability. We used an assay based on MTT, which is cleaved by viable cells. SW780 cells were transfected in quadruplicate with siRNAs against mock, LSR, TP53 and TP53+LSR. However, there was no significant viability difference between any of the knockdowns and the mock transfected cells (Additional File 6). Consequently, the invasive capacity upon LSR knockdown was not caused by a difference in number of viable cell.

\section{Cellular movement network using cell line and tumor derived expression data}

Since elevated invasion potential seemed to be an important functional consequence of LSR knockdown, we constructed a "cellular movement" network. 64 genes, which were differentially expressed upon knockdown of LSR and which were significantly related to the gene categories cellular movements, invasion and migration with p-values below $1.0 \times 10^{-10}$ were selected for network generation. 60 of these could be directly or indirectly connected using IPA. Then log ratios of mean expression $48 \mathrm{~h}$ after knockdown with LSR1 compared to mean expression after knockdown with mock siRNA were superimposed (Figure $8 \mathrm{~A})$. Further, from the microarray data from the clinical specimens we calculated mean expression values and log 
Table 2: "Global functional analysis" conducted using Ingenuity Pathway Analysis.

\begin{tabular}{|c|c|c|c|c|}
\hline Time after transfection & SIRNA & Category & Process Annotation & Significance \\
\hline \multirow[t]{20}{*}{$18 \mathrm{~h}$} & TP53 & Cell Death & cell death of tumor cell lines & $5.96 \mathrm{E}-09$ \\
\hline & & Organismal Survival & survival of mammalia & $9.59 \mathrm{E}-09$ \\
\hline & & Cell Death & cell death of lung cancer cell lines & $3.72 \mathrm{E}-08$ \\
\hline & & Organismal Survival & survival of mice & $9.84 \mathrm{E}-08$ \\
\hline & & Cellular Growth and Proliferation & colony formation of eukaryotic cells & I.48E-07 \\
\hline & LSRI & Cancer & proliferation of tumor cell lines & $3.78 \mathrm{E}-07$ \\
\hline & & $\begin{array}{l}\text { DNA Replication, Recombination, and } \\
\text { Repair }\end{array}$ & synthesis of DNA & 4.6IE-07 \\
\hline & & Cell Death & apoptosis of cell lines & I.67E-06 \\
\hline & & Cancer & cell death of tumor cell lines & $1.95 \mathrm{E}-06$ \\
\hline & & Organismal Survival & survival of mammalia & $2.29 \mathrm{E}-06$ \\
\hline & LSR2 & Cancer & growth of tumor cell lines & 2. IIE-07 \\
\hline & & Cellular Growth and Proliferation & growth of cell lines & 3.14E-07 \\
\hline & & Cancer & proliferation of tumor cell lines & I.38E-06 \\
\hline & & $\begin{array}{l}\text { Cardiovascular System Development and } \\
\text { Function }\end{array}$ & development of blood vessel & $1.78 \mathrm{E}-06$ \\
\hline & & Cellular Growth and Proliferation & growth of eukaryotic cells & $2.85 \mathrm{E}-06$ \\
\hline & TP53+LSR I & Cellular Growth and Proliferation & colony formation of eukaryotic cells & 5.07E-10 \\
\hline & & Organismal Survival & survival of mammalia & 8.79E-09 \\
\hline & & Cellular Growth and Proliferation & colony formation of cell lines & I.IIE-08 \\
\hline & & Cell Death & cell death of cell lines & $3.66 \mathrm{E}-08$ \\
\hline & & Cancer & colony formation of tumor cell lines & I.IIE-07 \\
\hline \multirow[t]{20}{*}{$48 \mathrm{~h}$} & TP53 & Cell-To-Cell Signaling and Interaction & activation of eukaryotic cells & I.I7E-10 \\
\hline & & Organismal Survival & survival of rodents & $1.74 \mathrm{E}-09$ \\
\hline & & Cellular Growth and Proliferation & proliferation of cell lines & $1.29 \mathrm{E}-08$ \\
\hline & & Cellular Growth and Proliferation & growth of central nervous system cells & I.76E-08 \\
\hline & & Cellular Growth and Proliferation & colony formation of cells & $3.72 \mathrm{E}-08$ \\
\hline & LSRI & Cellular Movement & cell movement & $3.26 \mathrm{E}-12$ \\
\hline & & Cellular Movement & invasion of eukaryotic cells & $2.3|\mathrm{E}-\mathrm{I}|$ \\
\hline & & Cellular Movement & invasion of cell lines & I.6IE-09 \\
\hline & & Cellular Movement & cell movement of cell lines & 3.84E-09 \\
\hline & & Cellular Movement & cell movement of endothelial cells & 4.24E-09 \\
\hline & LSR2 & Cellular Movement & cell movement & $2.72 \mathrm{E}-15$ \\
\hline & & Cellular Growth and Proliferation & growth of tumor cell lines & $4.45 \mathrm{E}-12$ \\
\hline & & Cellular Movement & cell movement of eukaryotic cells & $4.54 \mathrm{E}-12$ \\
\hline & & Cell-To-Cell Signaling and Interaction & adhesion of cells & $4.78 \mathrm{E}-12$ \\
\hline & & Cellular Movement & cell movement of cell lines & $7.54 \mathrm{E}-12$ \\
\hline & TP53+LSRI & Renal and Urological Disease & renal and urological disorder of rodents & $3.87 \mathrm{E}-08$ \\
\hline & & Renal and Urological Disease & renal and urological disorder of rats & I.05E-07 \\
\hline & & Cancer & growth of tumor cell lines & I.99E-07 \\
\hline & & Cellular Growth and Proliferation & colony formation of eukaryotic cells & $5.94 \mathrm{E}-07$ \\
\hline & & Cellular Growth and Proliferation & colony formation of cell lines & I.I8E-06 \\
\hline \multirow[t]{15}{*}{$72 \mathrm{~h}$} & TP53 & Tissue Development & development of tissue & 5.9IE-08 \\
\hline & & Tissue Development & angiogenesis of chorioallantoic membrane & $8.76 \mathrm{E}-08$ \\
\hline & & Renal and Urological Disease & renal and urological disorder of rodents & I.0IE-07 \\
\hline & & Cancer & angiogenesis of tumor & I.82E-07 \\
\hline & & Cellular Movement & cell movement & I.99E-07 \\
\hline & LSRI & Cellular Movement & cell movement & 8.99E-II \\
\hline & & Cellular Movement & migration of eukaryotic cells & 2.4IE-09 \\
\hline & & Cellular Movement & cell movement of eukaryotic cells & $2.46 \mathrm{E}-09$ \\
\hline & & Cellular Movement & cell movement of cell lines & 5.27E-09 \\
\hline & & Cellular Movement & migration of tumor cell lines & I.72E-08 \\
\hline & LSR2 & Cellular Movement & cell movement & $5.60 \mathrm{E}-15$ \\
\hline & & Cellular Movement & cell movement of eukaryotic cells & $2.46 \mathrm{E}-13$ \\
\hline & & Cellular Movement & migration of eukaryotic cells & 7.57E- 13 \\
\hline & & Cellular Growth and Proliferation & growth of tumor cell lines & $5.66 \mathrm{E}-12$ \\
\hline & & Tissue Development & formation of tissue & 8.77E-12 \\
\hline
\end{tabular}


Table 2: "Global functional analysis" conducted using Ingenuity Pathway Analysis. (Continued)

\begin{tabular}{|c|c|c|c|}
\hline TP53+LSRI & Cellular Movement & migration of eukaryotic cells & $4.19 \mathrm{E}-10$ \\
\hline & Cellular Movement & cell movement & $8.74 \mathrm{E}-10$ \\
\hline & Cellular Movement & cell movement of eukaryotic cells & I.57E-09 \\
\hline & Cancer & angiogenesis of tumor & $6.86 \mathrm{E}-09$ \\
\hline & Renal and Urological Disease & renal and urological disorder of rodents & 8.15E-09 \\
\hline
\end{tabular}

The list includes the annotation of the differentially expressed genes upon knockdown. The likelihood that the association between a set of differentially expressed genes and a given function was due to chance was calculated using the right-tailed Fisher's exact test. The biological functions or processes annotated to affected genes are listed according to their significance.

ratios between tumor and normal urothelium samples, for the same gene set. These data were superimposed the same cell movement network (Figure 8B). The correlation between the gene expression for the two dataset was marginally significant (Kendall's tau b, one-sided $\mathrm{p}$-value $=$ 0.0526). However, the complexity of the clinical samples makes this an interesting finding.

\section{Motility}
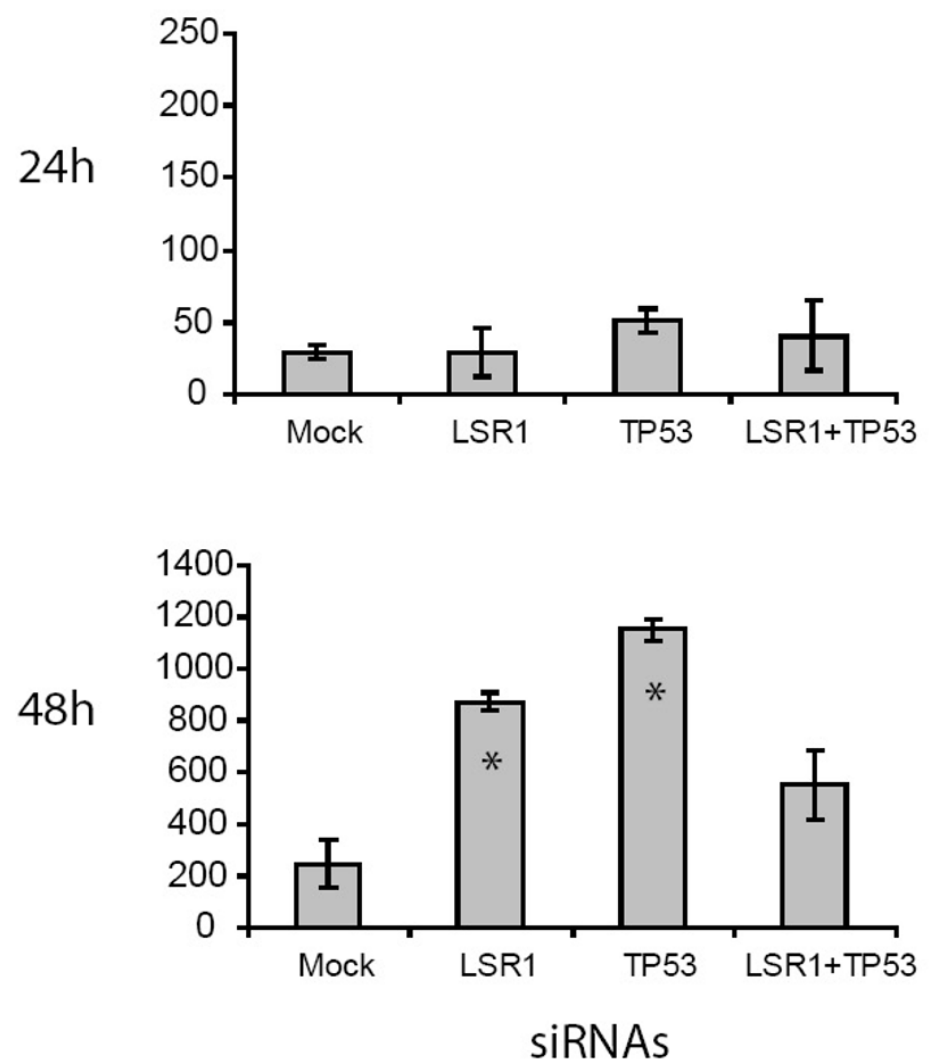

\section{Discussion}

We investigated the functional role of LSR in vitro by transient transfection of LSR and TP53 siRNAs into a bladder cancer cell line (SW780) followed by microarray measurements of gene expression. We used Ingenuity Pathway Analysis to investigate the relationship among differentially expressed genes upon knockdown and thereby, to

Figure 7

Cell invasion assay. Cells were transfected with siRNAs (Mock, LSRI, TP53, LSRI+TP53) and were allowed to grow for 24 $\mathrm{h}$ or $48 \mathrm{~h}$ in control inserts (three samples per transfection) or in matrigel matrix inserts (three samples per transfection). The mean number of cells passing the inserts was calculated. Error bars indicate $+/$ - one standard error. Asterisks (*) indicate transfections where the number of cells passing the membrane was significantly different from the mock transfected cells.

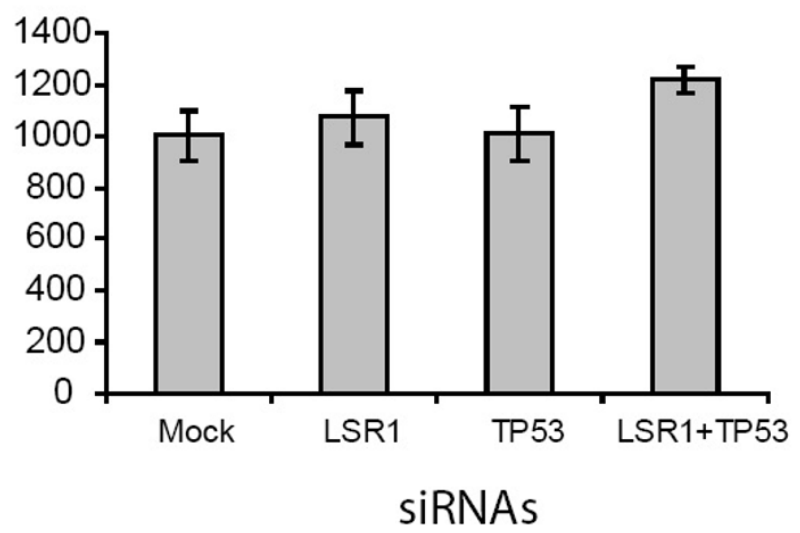


A

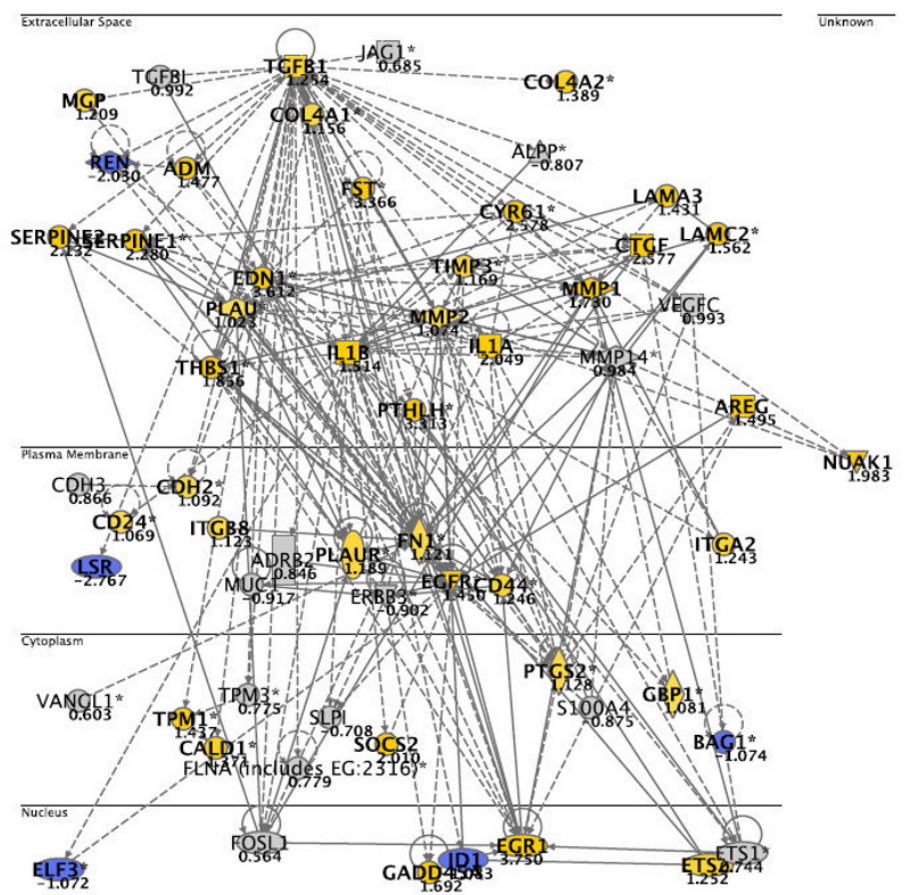

@e000-2007 Ingenuity Systems, Inc. All rights reserved.

\section{B}

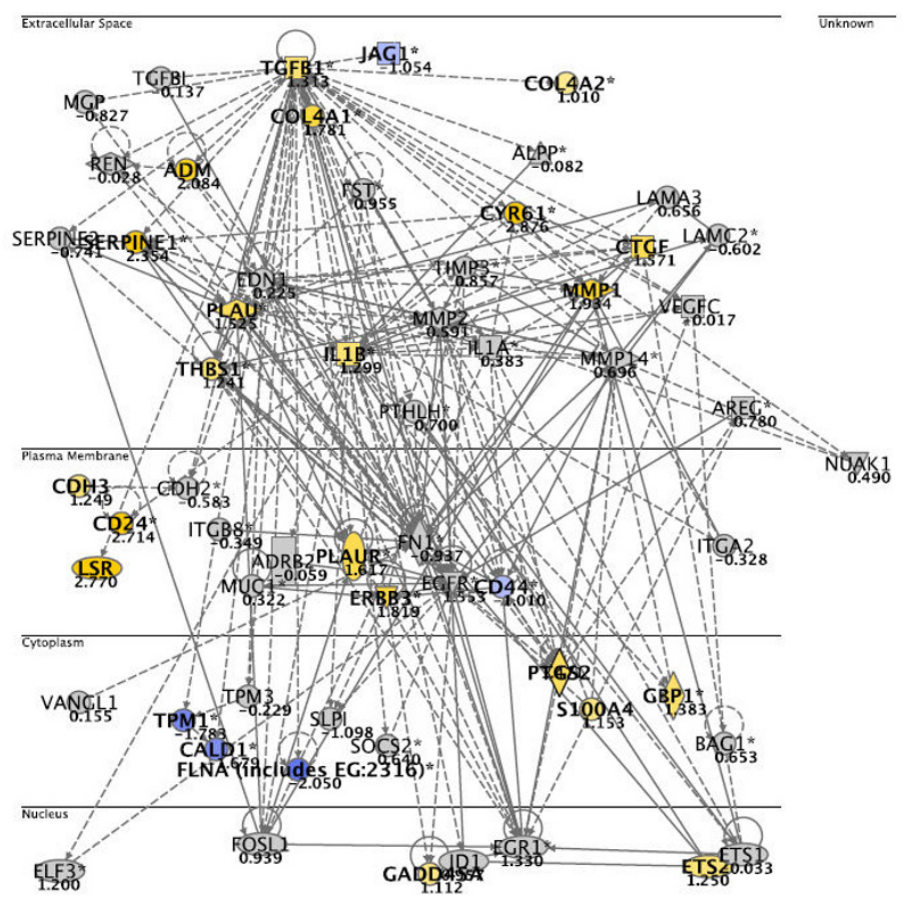

Figure 8

Cellular movement and invasion network. $\mathrm{A}$; log ratios of mean expression $48 \mathrm{~h}$ after knockdown with LSR I compared to mean expression $48 \mathrm{~h}$ after knockdown with mock siRNA were overlaid. B; microarray data from 87 bladder tumors and 9 normal urothelium samples superimposed the cell movement network. Yellow represents up-regulated genes and blue represents down-regulated genes. Genes not fulfilling the cut-off criteria are not colored. 
generate hypotheses and to suggest directions for further phenotypic analyses. We identified six gene networks containing genes mainly related to the functional categories "cancer", "cell death", and "cellular movement". Further, by investigating the entire dataset, we determined that genes annotated to the functional category "cellular movement", including "invasion" and "cell motility", were highly significantly overrepresented among the differentially expressed genes after LSR knockdown. We investigated the role of these genes in a phenotypic matrigel assay, which showed that the invasion capacity was significantly elevated $24 \mathrm{~h}$ after transfection with LSR1 or TP53 siRNAs compared to mock transfected cells, while the motility capacity was significantly elevated $48 \mathrm{~h}$ after transfection with LSR1 or TP53. The motility and invasion capacity was controlled for cell viability. These results indicate that in the urinary bladder LSR plays a role in cancer development.

The role of LSR has been thoroughly investigated in humans, rats and mice $[12-15,17,26]$. LSR is mainly expressed in liver membranes $[13,15,17]$ and is believed to mediate clearance of chylomicrons after activations of free fatty acids $[13,14]$. However, other functions may exist, since LSR is also expressed in other tissues [20,2729]. LSR expression has been shown in tumor tissue like ovarian cancer, where LSR was one of thirty genes identified as a potential tumor marker [29].

A relationship between LSR, transforming growth-factor $\beta 1$ (TGF- $\beta 1$ ) and Smad4 has been investigated in relation to cell movements measured by a wound closure assay [20]. TGF- $\beta$ induced signalling can be induced in a Smad 4 dependent and independent way. Briefly, the experiment showed that in presence of Smad4, TGF- $\beta 1$ stimulation depressed LSR expression and induced cell movements. Upon TGF- $\beta 1$ stimulation in Smad4 knocked down cells, LSR was not reduced and migration was delayed. TGFB1 has also been associated with cell migration [30].

In our in vitro experiment we found that TGF- $\beta 1$ was upregulated more than 2-fold after knockdown of LSR (Figure 8A). Similar, we saw that TGF- $\beta 1$ expression was upregulated in vivo. Further, our invasion assay showed that the invasion and migration capacity was elevated when LSR was downregulated, consistent with the findings by Jazag et al. These results suggest that TGF- $\beta 1$ expression can be regulated by the LSR level. Smad4 was not differentially expressed and was not included in the analysis.

The data document that it is quite useful to conduct timecourse microarray studies and to use in-silico data mining, such as network and functional network analysis, to understand the effect of single molecules. In the present case we would not have identified the invasion and motility effect of LSR had it not been suggested by the pathway analysis.

In an effort to handle possible off-target effects we included two different siRNAs against LSR. Both siRNAs demonstrated a comparable knockdown effect of LSR. Sixteen genes were constitutively regulated over time by both LSR siRNAs. Among these were CYR61, which has been shown to be overexpressed and associated with advanced stages of breast cancer [31], and EGR1, which is believed to be a direct regulator of tumor suppressors like TGFB1, TP53 and PTEN [32]. EGR1 was upregulated upon knockdown of LSR in vitro and upregulated when comparing tumor samples with normal urothelium samples, though not significantly. Finally, the "local network analysis" and the "global functional analysis" conducted in IPA showed overall the same findings. Therefore, we believe that our LSR siRNAs mainly target the same LSR transcript and that possible off-target effects are minimal.

We included knockdown of TP53 for two reasons: First, LSR was previously identified as a potential primary target of TP53 [19]. In our experiment we could not see any effect on LSR transcription after TP53 knockdown and vice versa. Secondly, we included knockdown of TP53 as a control model in our in silico investigations. Both the "local network analysis" and the "global functional analysis" showed that genes affected by TP53 knockdown could be related to cancer and cell death.

\section{Conclusion}

LSR may be involved in both invasion, and cellular movement in bladder cancer. Future research will document whether LSR-like molecules could be used therapeutically in bladder cancer treatment.

\section{Competing interests}

The authors declare that they have no competing interests.

\section{Authors' contributions}

MH, KB-D, TT, CW, TFØ and LD participated in the study design. MH performed most of the microarray analyses and invasion assays. KBD participated in the IHC work. MH drafted the paper. MH, KBD, TFØ and LD participated in the final preparation of the paper. All authors read and approved the final manuscript. 


\section{Additional material}

\section{Additional file 1}

Antibody generation. CULSTALW1.83 analysis of the three isoforms and the peptide used for immunization of rabbits.

Click here for file

[http://www.biomedcentral.com/content/supplementary/17558794-1-31-S1.doc]

\section{Additional file 2}

IHC results. Immunohistochemical staining of LSR in 40 bladder tumor samples.

Click here for file

[http://www.biomedcentral.com/content/supplementary/17558794-1-31-S2.doc]

\section{Additional file 3}

Comparison of number of genes differentially expressed. A: Number of probes differentially expressed $(L R \geq|1|)$ by both LSR siRNAs (LSR1 and LSR2) at three different time points. B: Number of probes differentially expressed (LR $\geq|1|)$ by the same LSR siRNA (LSR1 or LSR2) at three different time points. C: Number of probes differentially expressed ( $L R \geq$ |1|) by both LSR siRNAs (LSR1 and LSR2) at all three time points. Click here for file

[http://www.biomedcentral.com/content/supplementary/17558794-1-31-S3.doc]

\section{Additional file 4}

Gene expression data. Genes found to be differentially expressed upon knockdown.

Click here for file

[http://www.biomedcentral.com/content/supplementary/17558794-1-31-S4.xls]

\section{Additional file 5}

Functional categories. Overview of functional categories related to differentially expressed genes in top ranked "local networks".

Click here for file

[http://www.biomedcentral.com/content/supplementary/17558794-1-31-S5.doc]

\section{Additional file 6}

Viability assay. A MTT ELISA assay was used to test the impact of LSR and TP53 knockdown on cell viability. SW780 cells were transfected in quadruplicate with siRNAs against mock, LSR, TP53 and TP53+LSR. 24 $h, 48 h$ or $72 h$ after transfection MTT was added and cells were allowed to incubate for four hours. Then the cells were lysed and the absorbance was measured at $540 \mathrm{~nm}$ and $690 \mathrm{~nm}$ (reference) on an ELISA reader. Click here for file

[http://www.biomedcentral.com/content/supplementary/17558794-1-31-S6.doc]

\section{Acknowledgements}

We would like to acknowledge Professor J.L. Jensen for statistical guidelines concerning the experimental setup of the time-course experiment and Susanne Bruun, Lisbeth Kjeldsen, and Pamela Celis for excellent technical assistance. The project was supported by the Danish Cancer Society and the Danish School in Molecular Cancer Research School.

\section{References}

I. Lander ES, Linton LM, Birren B, Nusbaum C, Zody MC, Baldwin J, Devon K, Dewar K, Doyle M, FitzHugh W, Funke R, Gage D, Harris K, Heaford A, Howland J, Kann L, Lehoczky J, LeVine R, McEwan P, McKernan K, Meldrim J, Mesirov JP, Miranda C, Morris W, Naylor J, Raymond C, Rosetti M, Santos R, Sheridan A, Sougnez C, StangeThomann N, Stojanovic N, Subramanian A, Wyman D, Rogers J, Sulston J, Ainscough R, Beck S, Bentley D, Burton J, Clee C, Carter N, Coulson A, Deadman R, Deloukas P, Dunham A, Dunham I, Durbin R, French L, Grafham D, Gregory S, Hubbard T, Humphray S, Hunt A, Jones M, Lloyd C, McMurray A, Matthews L, Mercer S, Milne S, Mullikin JC, Mungall A, Plumb R, Ross M, Shownkeen R, Sims S, Waterston RH, Wilson RK, Hillier LW, McPherson JD, Marra MA Mardis ER, Fulton LA, Chinwalla AT, Pepin KH, Gish WR, Chissoe SL, WendI MC, Delehaunty KD, Miner TL, Delehaunty A, Kramer JB, Cook LL, Fulton RS, Johnson DL, Minx PJ, Clifton SW, Hawkins T, Branscomb E, Predki P, Richardson P, Wenning S, Slezak T, Doggett $\mathrm{N}$, Cheng JF, Olsen A, Lucas S, Elkin C, Uberbacher E, Frazier M, Gibbs RA, Muzny DM, Scherer SE, Bouck JB, Sodergren EJ, Worley KC, Rives CM, Gorrell JH, Metzker ML, Naylor SL, Kucherlapati RS, Nelson DL, Weinstock GM, Sakaki Y, Fujiyama A, Hattori M, Yada T, Toyoda A, Itoh T, Kawagoe C, Watanabe H, Totoki Y, Taylor T, Weissenbach J, Heilig R, Saurin W, Artiguenave F, Brottier P, Bruls T, Pelletier E, Robert C, Wincker P, Smith DR, Doucette-Stamm L, Rubenfield M, Weinstock K, Lee HM, Dubois J, Rosenthal A, Platzer M, Nyakatura G, Taudien S, Rump A, Yang H, Yu J, Wang J, Huang G, Gu J, Hood L, Rowen L, Madan A, Qin S, Davis RW, Federspiel NA, Abola AP, Proctor MJ, Myers RM, Schmutz J, Dickson M, Grimwood J, Cox DR, Olson MV, Kaul R, Raymond C, Shimizu N, Kawasaki K, Minoshima S, Evans GA, Athanasiou M, Schultz R, Roe BA, Chen F, Pan H, Ramser J, Lehrach H, Reinhardt R, McCombie WR, de la BM, Dedhia N, Blocker H, Hornischer K, Nordsiek G, Agarwala R, Aravind L, Bailey JA, Bateman A, Batzoglou S, Birney E, Bork P, Brown DG, Burge CB, Cerutti L, Chen HC, Church D, Clamp M, Copley RR, Doerks T, Eddy SR, Eichler EE, Furey TS, Galagan J, Gilbert JG, Harmon C, Hayashizaki Y, Haussler D, Hermjakob H, Hokamp K, Jang W, Johnson LS, Jones TA, Kasif S, Kaspryzk A, Kennedy S, Kent WJ, Kitts P, Koonin EV, Korf I, Kulp D, Lancet D, Lowe TM, McLysaght A, Mikkelsen T, Moran JV, Mulder N, Pollara VJ, Ponting CP, Schuler G, Schultz J, Slater G, Smit AF, Stupka E, Szustakowski J, Thierry-Mieg D, Thierry-Mieg J, Wagner L, Wallis J, Wheeler R, Williams A, Wolf YI, Wolfe KH, Yang SP, Yeh RF, Collins F, Guyer MS, Peterson J, Felsenfeld A, Wetterstrand KA, Patrinos A, Morgan MJ, de JP, Catanese JJ, Osoegawa K, Shizuya H, Choi S, Chen YJ: Initial sequencing and analysis of the human genome. Nature 200I, 409:860-92I.

2. Venter JC, Adams MD, Myers EW, Li PW, Mural RJ, Sutton GG, Smith HO, Yandell M, Evans CA, Holt RA, Gocayne JD, Amanatides P, Ballew RM, Huson DH, Wortman JR, Zhang Q, Kodira CD, Zheng XH, Chen L, Skupski M, Subramanian G, Thomas PD, Zhang J, Gabor Miklos GL, Nelson C, Broder S, Clark AG, Nadeau J, McKusick VA, Zinder N, Levine AJ, Roberts RJ, Simon M, Slayman C, Hunkapiller M, Bolanos R, Delcher A, Dew I, Fasulo D, Flanigan M, Florea L, Halpern A, Hannenhalli S, Kravitz S, Levy S, Mobarry C, Reinert K, Remington K, bu-Threideh J, Beasley E, Biddick K, Bonazzi V, Brandon R, Cargill M, Chandramouliswaran I, Charlab R, Chaturvedi K, Deng Z, Di F V, Dunn P, Eilbeck K, Evangelista C, Gabrielian AE, Gan W, Ge W, Gong F, Gu Z, Guan P, Heiman TJ, Higgins ME, Ji RR, Ke Z, Ketchum KA, Lai Z, Lei Y, Li Z, Li J, Liang Y, Lin X, Lu F, Merkulov GV, Milshina N, Moore HM, Naik AK, Narayan VA, Neelam B, Nusskern D, Rusch DB, Salzberg S, Shao W, Shue B, Sun J, Wang Z, Wang A, Wang X, Wang J, Wei M, Wides R, Xiao C, Yan C, Yao A, Ye J, Zhan M, Zhang W, Zhang $\mathrm{H}$, Zhao Q, Zheng L, Zhong F, Zhong W, Zhu S, Zhao S, Gilbert D, Baumhueter S, Spier G, Carter C, Cravchik A, Woodage T, Ali F, An H, Awe A, Baldwin D, Baden H, Barnstead M, Barrow I, Beeson K, Busam D, Carver A, Center A, Cheng ML, Curry L, Danaher S, Davenport L, Desilets R, Dietz S, Dodson K, Doup L, Ferriera S, Garg N, Gluecksmann A, Hart B, Haynes J, Haynes C, Heiner C, Hladun S, Hostin D, Houck J, Howland T, Ibegwam C, Johnson J, Kalush F, Kline L, Koduru S, Love A, Mann F, May D, McCawley S, McIntosh T, McMullen I, Moy M, Moy L, Murphy B, Nelson K, Pfannkoch C, Pratts E, Puri V, Qureshi H, Reardon M, Rodriguez R, Rogers YH, Romblad D, Ruhfel B, Scott R, Sitter C, Smallwood M, Stewart E, Strong R, Suh E, Thomas R, Tint NN, Tse S, Vech C, Wang G, Wetter J, Williams S, Williams M, Windsor S, Winn-Deen E, Wolfe K, Zaveri J, Zaveri K, Abril JF, Guigo R, Campbell MJ, Sjolander KV, Karlak B, Kejariwal A, Mi H, Lazareva B, Hatton T, Narechania A, Diemer K, 
Muruganujan A, Guo N, Sato S, Bafna V, Istrail S, Lippert R, Schwartz R, Walenz B, Yooseph S, Allen D, Basu A, Baxendale J, Blick L, Caminha M, Carnes-Stine J, Caulk P, Chiang YH, Coyne M, Dahlke C, Mays A, Dombroski M, Donnelly M, Ely D, Esparham S, Fosler C, Gire H, Glanowski S, Glasser K, Glodek A, Gorokhov M, Graham K, Gropman B, Harris M, Heil J, Henderson S, Hoover J, Jennings D, Jordan C, Jordan J, Kasha J, Kagan L, Kraft C, Levitsky A, Lewis M, Liu X, Lopez J, Ma D, Majoros W, McDaniel J, Murphy S, Newman M, Nguyen T, Nguyen N, Nodell M: The sequence of the human genome. Science 200I, 29 I: |304-I35|.

3. Thykjaer T, Workman C, Kruhoffer M, Demtroder K, Wolf $\mathrm{H}$, Andersen LD, Frederiksen CM, Knudsen S, Orntoft TF: Identification of gene expression patterns in superficial and invasive human bladder cancer. Cancer Research 200 I, 6 I:2492-2499.

4. Dyrskjot L, Thykjaer T, Kruhoffer M, Jensen JL, Marcussen N, Hamilton-Dutoit $\mathrm{S}$, Wolf $\mathrm{H}$, Orntoft TF: Identifying distinct classes of bladder carcinoma using microarrays. Nat Genet 2003, 33:90-96.

5. Aaboe M, Marcussen N, Jensen KM, Thykjaer T, Dyrskjot L, Orntoft TF: Gene expression profiling of noninvasive primary urothelial tumours using microarrays. Br J Cancer 2005, 93: I I82- I I 90.

6. Blaveri E, Simko JP, Korkola JE, Brewer JL, Baehner F, Mehta K, DeVries S, Koppie T, Pejavar S, Carroll P, Waldman FM: Bladder cancer outcome and subtype classification by gene expression. Clin Cancer Res 2005, I I:4044-4055.

7. Wild PJ, Herr A, Wissmann C, Stoehr R, Rosenthal A, Zaak D, Simon R, Knuechel R, Pilarsky C, Hartmann A: Gene expression profiling of progressive papillary noninvasive carcinomas of the urinary bladder. Clin Cancer Res 2005, I I:44I5-4429.

8. Dyrskjot L, Zieger K, Kruhoffer M, Thykjaer T, Jensen JL, Primdahl H, Aziz N, Marcussen N, Moller K, Orntoft TF: A molecular signature in superficial bladder carcinoma predicts clinical outcome. Clin Cancer Res 2005, I I:4029-4036.

9. Sanchez-Carbayo M, Socci ND, Lozano J, Saint F, Cordon-Cardo C: Defining molecular profiles of poor outcome in patients with invasive bladder cancer using oligonucleotide microarrays. J Clin Oncol 2006, 24:778-789.

10. Takata R, Katagiri T, Kanehira M, Tsunoda T, Shuin T, Miki T, Namiki M, Kohri K, Matsushita Y, Fujioka T, Nakamura Y: Predicting response to methotrexate, vinblastine, doxorubicin, and cisplatin neoadjuvant chemotherapy for bladder cancers through genome-wide gene expression profiling. Clin Cancer Res 2005, II:2625-2636.

II. Knowles MA: Molecular subtypes of bladder cancer: Jekyll and Hyde or chalk and cheese? Carcinogenesis 2006, 27:361-373.

12. Bihain $B E$, Yen FT: Free fatty acids activate a high-affinity saturable pathway for degradation of low-density lipoproteins in fibroblasts from a subject homozygous for familial hypercholesterolemia. Biochemistry 1992, 31:4628-4636.

13. Yen FT, Mann CJ, Guermani LM, Hannouche NF, Hubert N, Hornick CA, Bordeau VN, Agnani G, Bihain BE: Identification of a lipolysisstimulated receptor that is distinct from the LDL receptor and the LDL receptor-related protein. Biochemistry 1994, 33:1172-1180

14. Mann CJ, Khallou J, Chevreuil O, Troussard AA, Guermani LM, Launay K, Delplanque B, Yen FT, Bihain BE: Mechanism of activation and functional significance of the lipolysis-stimulated receptor. Evidence for a role as chylomicron remnant receptor. Biochemistry 1995, 34: 1042I-10431.

15. Yen FT, Masson M, Clossais-Besnard N, Andre P, Grosset JM, Bougueleret L, Dumas JB, Guerassimenko O, Bihain BE: Molecular cloning of a lipolysis-stimulated remnant receptor expressed in the liver. J Biol Chem 1999, 274: I3390-13398.

16. Bihain BE, Yen FT: The lipolysis stimulated receptor: a gene at last. Curr Opin Lipidol 1998, 9:221-224.

17. Troussard AA, Khallou J, Mann CJ, Andre P, Strickland DK, Bihain BE, Yen FT: Inhibitory effect on the lipolysis-stimulated receptor of the 39-kDa receptor-associated protein. J Biol Chem 1995, 270: |7068-|707|

18. Mann CJ, Troussard AA, Yen FT, Hannouche N, Najib J, Fruchart JC Lotteau V, Andre P, Bihain BE: Inhibitory effects of specific apolipoprotein C-III isoforms on the binding of triglyceride-rich lipoproteins to the lipolysis-stimulated receptor. J Biol Chem 1997, 272:31348-31354.

19. Kannan K, Amariglio N, Rechavi G, Jakob-Hirsch J, Kela I, Kaminski N, Getz G, Domany E, Givol D: DNA microarrays identification of primary and secondary target genes regulated by $\mathrm{p} 53$. Oncogene 200I, 20:2225-2234

20. Jazag A, ljichi H, Kanai F, Imamura T, Guleng B, Ohta M, Imamura J, Tanaka Y, Tateishi K, Ikenoue T, Kawakami T, Arakawa Y, Miyagishi $M$, Taira K, Kawabe T, Omata M: Smad4 silencing in pancreatic cancer cell lines using stable RNA interference and gene expression profiles induced by transforming growth factorbeta. Oncogene 2005, 24:662-671.

2I. Birkenkamp-Demtroder K, Wagner L, Brandt SF, Bording AL, Gartner W, Scherubl H, Heine B, Christiansen P, Orntoft TF: Secretagogin is a novel marker for neuroendocrine differentiation. Neuroendocrinology 2005, 82:121-138.

22. Amaxa $h t t p: / / w w w$ amaxa com 2008 [http://www.amaxa.com].

23. Wu Z, Irizarry RA: Preprocessing of oligonucleotide array data. Nat Biotechnol 2004, 22:656-658.

24. Bioconductor 2008 [http://www.bioconductor.org]

25. Jackson AL, Bartz SR, Schelter J, Kobayashi SV, Burchard J, Mao M, Li B, Cavet G, Linsley PS: Expression profiling reveals off-target gene regulation by RNAi. Nat Biotechnol 2003, 21:635-637.

26. Mesli S, Javorschi S, Berard AM, Landry M, Priddle H, Kivlichan D, Smith AJ, Yen FT, Bihain BE, Darmon M: Distribution of the lipolysis stimulated receptor in adult and embryonic murine tissues and lethality of LSR-/- embryos at I 2.5 to I4.5 days of gestation. Eur J Biochem 2004, 27 I:3 103-3 I I4.

27. Reese J, Das SK, Paria BC, Lim H, Song H, Matsumoto H, Knudtson $\mathrm{KL}$, DuBois RN, Dey SK: Global gene expression analysis to identify molecular markers of uterine receptivity and embryo implantation. J Biol Chem 200I, 276:44|37-44|45.

28. Moraes RC, Blondet A, Birkenkamp-Demtroeder K, Tirard J, Orntoft TF, Gertler A, Durand P, Naville D, Begeot M: Study of the alteration of gene expression in adipose tissue of diet-induced obese mice by microarray and reverse transcriptionpolymerase chain reaction analyses. Endocrinology 2003, 144:4773-4782.

29. Welsh JB, Zarrinkar PP, Sapinoso LM, Kern SG, Behling CA, Monk BJ, Lockhart DJ, Burger RA, Hampton GM: Analysis of gene expression profiles in normal and neoplastic ovarian tissue samples identifies candidate molecular markers of epithelial ovarian cancer. Proc Natl Acad Sci U S A 200 I, 98: I I76-I I8I.

30. Morton DM, Barrack ER: Modulation of transforming growth factor beta I effects on prostate cancer cell proliferation by growth factors and extracellular matrix. Cancer Res 1995, 55:2596-2602.

31. Xie D, Miller CW, O'Kelly J, Nakachi K, Sakashita A, Said JW, Gornbein J, Koeffler HP: Breast cancer. Cyr6I is overexpressed, estrogen-inducible, and associated with more advanced disease. J Biol Chem 200I, 276:14187-I4194.

32. Baron V, Adamson ED, Calogero A, Ragona G, Mercola D: The transcription factor Egrl is a direct regulator of multiple tumor suppressors including TGFbetal, PTEN, p53, and fibronectin. Cancer Gene Ther 2006, 1 3: I I 5-124.

\section{Pre-publication history}

The pre-publication history for this paper can be accessed here:

http://www.biomedcentral.com/1755-8794/1/31/prepub 